\title{
PENGARUH PEMBELAJARAN BERBASIS PENEMUAN TERBIMBING TERHADAP PENINGKATAN KEMAMPUAN PENALARAN MATEMATIS
}

\author{
Taufik Rahman ${ }^{* 1}$, Nis Maya ${ }^{2}$ \\ Jalan Tamansari No 6-8, (022)4205317/Fax 4263982/Bandung 40166 \\ Pendidikan Matematika Fakultas Keguruan dan Ilmu Pendidikan \\ Universitas Pasundan Bandung \\ Email: "taufikaja54@gmail.com
}

\begin{abstract}
Abstrak. Kemampuan yang dianalisis dalam penelitian ini adalah kemampuan penalaran matematis. Penalaran matematis dirasa penting karena kemampuan ini tertuang dalam tujuan pembelajaran matematika SMA yang berbunyi memperoleh penalaran pada pola dan sifat, melakukan manipulasi matematika dalam membuat generalisasi, menyusun bukti, atau menjelaskan gagasan dan pernyataan matematika. Penelitian ini bertujuan untuk mengetahui peningkatan kemampuan penalaran matematis siswa di salah satu SMK di Kota Bandung antara yang memperoleh pembelajaran penemuan terbimbing dengan yang memperoleh pembelajaran saintifik. Sampel dalam penelitian ini adalah salah satu SMK di Kota Bandung yang dipilih sebanyak 2 kelas yaitu kelas pertama memperoleh pembelajaran penemuan terbimbing dan kelas kedua memperoleh pembelajaran saintifik. Metode dalam penelitian ini adalah kuasi ekperimen. Instrumen dalam penelitian ini adalah instrument tes yang berbentuk uraian dan terdiri dari 5 soal. Hasil dari Penelitian ini adalah tidak terdapat perbedaan yang signifikan antara peningkatan kemampuan penalaran matematis siswa yang memperoleh pembelajaram penemuan terbimbing dengan siswa yang memperoleh pembelajaran saintifik.
\end{abstract}

Kata Kunci: Kemampuan Penalaran Matematis, Penemuan Terbimbing.

\begin{abstract}
Ability has been analyzed in this research is the ability of mathematical reasoning. Mathematical reasoning is important because this ability is contained in the objectives of high school mathematics learning which sounds to gain reasoning on patterns and traits, perform mathematical manipulations in generalizing, compiling evidence, or explaining mathematical ideas and statements. This research aims to determine the improvement of students' mathematical reasoning abilities in one of the vocational schools in Bandung between those who received learning guided discovery with who acquired scientific learning. The sample in this research is one of the SMK in Bandung which is chosen as much as 2 classes, the first class gets the learning of guided discovery and the second class obtains scientific study. The method in this research is quasi experiment. Instruments in this research is a test instrument and consists of 5 essay questions. The result of this research shows that there is no significant difference between the improvement of students' mathematical reasoning ability that obtains learners of guided discovery with students who get scientific study.
\end{abstract}

Keywords: Mathematical reasoning ability, Guided Discovery

\section{Pendahuluan}

Kemampuan penalaran merupakan proses berfikir dalam proses penarikan kesimpulan (Sumarmo, 2013). Dalam kurikulum matematika sekolah, penalaran merupakan komponen dasar matematika yang harus dikuasai siswa sekolah menengah. Hal ini sejalan dengan Salah 
satu tujuan pembelajaran Matematika SMA menurut standar isi untuk satuan pendidikan (BSNP : 2006) adalah sebagai berikut.

1. Memperoleh penalaran pada pola dan sifat, melakukan manipulasi matematika dalam membuat generalisasi, menyusun bukti, atau menjelaskan gagasan dan pernyataan matematika.

2. Mengomunikasikan gagasan dengan simbol, tabel, diagram, atau media lain untuk memperjelas keadaan atau masalah.

3. Memiliki sikap menghargai kegunaan matematika dalam kehidupan, yaitu memiliki rasa ingin tahu, perhatian, dan minat dalam mempelajari matematika, serta sikap ulet dan percaya diri dalam pemecahan masalah.

Tujuan pembelajaran matematika diatas, salah satunya meningkatkan penalaran matematis. Hal ini sejalan dengan pendapat dari Wahyudin (2007) bahwa salah satu standar proses untuk matematika sekolah adalah meningkatkan kemampuan penalaran matematis siswa.

Berdasarkan informasi di atas, kemampuan penalaran matematis cukup penting. Hal ini sejalan dengan de lange (Shadiq, 2009) salah satu kemampuan yang harus dikembangkan dalam pendidikan matematika adalah kemampuan penalaran matematis siswa. Wahyudin (2007) menyatakan bahwa kemampuan penalaran sangat penting untuk memahami matematika. Materi matematika dipahami melalui penalaran dan penalaran dipahami dan dilatihkan melalui belajar materi matematika

Faktanya dilapangan, dengan diterapkanya kurikulum 2013 yang menggunakan pendekatan saintifik dalam proses pembelajaan, berdasarkan studi pendahuluan yang telah peneliti lakukan pada suatu SMK Negeri di kota Bandung menunjukkan bahwa kemampuan penalaran matematis siswa masih membutuhkan perhatian khusus. Hal ini dapat dilihat dari hasil tes kemampuan penalaran matematis yang diperoleh yaitu untuk kemampuan penalaran diperoleh rata-rata skor 58 dari idealnya 100. Selain itu, dari hasil pengamatan selama pembelajaran di kelas, siswa masih kurang menggunakan nalarnya dalam menarik kesimpulan. Contohnya seperti siswa kebingungan untuk menarik kesimpulan dari beberapa kasus yang diberikan. Disamping itu pula, siswa masih merasa kesulitan ketika guru menyuruh siswa untuk menyatakan suatu situasi ke dalam bahasa simbol atau model matematik.

Solusi untuk memecahkan masalah yang ada dalam pembelajaran matematika khususnya untuk meningkatkan kemampuan penalaran matematis, diperlukan suatu pembelajaran yang efektif dan efisien. Salah satu solusi yang peneliti ajukan untuk meningkatkan kemampuan diatas adalah dengan menerapkan pembelajaran dengan penemuan terbimbing. Menurut Markaban (2006) bahwa penggunaan model penemuan terbimbing dalam belajar matematika dapat meningkatkan kemampuan penalaran siswa. Lebih lanjut menurut Ruseffendi (2010) belajar penemuan itu penting, sebab matematika adalah bahasa yang abstrak dan akan lebih melekat bila melalui metode penemuan. Disamping itu, dengan penemuan terbimbing sikap positif pada diri siswa akan tumbuh karena proses pembelajaran berpusat pada siswa. Hal ini sejalan dengan pendapat Nasution (2009) bahwa melibatkan siswa secara sepenuhnya dalam pembelajaran dan menemukan sendiri konsep dari suatu 
materi yang diajarkan maka akan menumbuhkan sikap yang positif terhadap siswa. Di dalam pandangan Bruner, belajar dengan penemuan adalah belajar untuk menemukan, dimana seorang siswa dihadapkan dengan suatu masalah atau situasi yang tampaknya ganjil sehingga siswa dapat mencari jalan pemecahan (Markaban, 2006).

Penerapan model penemuan terbimbing dalam pembelajaran matematika, memungkinkan terjadi proses interaksi dengan tujuannya untuk saling mempengaruhi berpikir masing-masing, guru memancing berpikir siswa yaitu dengan pertanyaan-pertanyaan terfokus sehingga dapat memungkinkan siswa untuk memahami dan mengkontruksikan konsep-konsep tertentu, membangun aturan-aturan dan belajar menemukan sesuatu untuk memecahkan masalah (Markaban, 2006). Dengan model penemuan terbimbing siswa dihadapkan kepada situasi dimana siswa bebas menyelidiki dan menarik kesimpulan (Markaban, 2006). Itu semua sejalan untuk meningkatkan penalaran matematis siswa. Sehingga siswa yang belajar dengan penemuan terbimbing dapat diharapkan akan meningkatkan kemampuan siswa dalam mengerjakan soal matematika, karena siswa dilibatkan dalam berpikir matematika pada saat manipulasi, eksperimen, dan menyelesaikan masalah.

Untuk mengatasi masalah di atas, perlu diadakan penelitian tentang pengaruh pembelajaran berbasis penemuan terbimbing terhadap kemampuan penalaran matematis. Dengan serangkaian tindakan, mulai dari perencanaan, pelaksanaan, sampai dengan evaluasi, diharapkan dapat meningkatkan kemampuan penalaran matematis siswa dalam memahami materi.

\section{Metode Penelitian}

Desain eksperimen yang dimaksud dalam penelitian ini terdapat dua kelompok eksperimen yang diambil secara acak kelas, yaitu Kelompok siswa yang diberikan pembelajaran dengan model penemuan terbimbing dan kelompok siswa yang diberikan pembelajaran saintifik. Peneliti berusaha agar kelompok tersebut seserupa mungkin, sehingga untuk melihatnya diberikan tes awal (pretest) untuk kedua kelompok sebelum perlakuan diberikan, kemudian setelah perlakuan diberikan kepada masing-masing kelompok, maka diberikan tes akhir (posttest). Soal yang diberikan untuk tes awal dan tes akhir merupakan soal yang serupa. Berikut merupakan gambaran desain penelitian.

$$
\begin{array}{llll}
\mathrm{R} & \mathrm{O} & \mathrm{X}_{1} & \mathrm{O} \\
\mathrm{R} & \mathrm{O} & \mathrm{X}_{2} & \mathrm{O}
\end{array}
$$

Keterangan :

$\mathrm{R} \quad$ : pengambilan sampel secara acak kelompok

$\mathrm{O} \quad$ : tes awal/tes akhir

$\mathrm{X}_{1}$ : pembelajaran penemuan terbimbing

$\mathrm{X}_{2} \quad$ : pembelajaran saintifik

Solomon (Wahyudin, 2014)

Penelitian ini dilaksanakan di SMKN di Bandung. Selanjutnya di pilih SMKN 4 Bandung sebagai lokasi penelitian. Populasi dalam penelitian ini adalah seluruh siswa kelas 
10 di SMKN 4 Bandung. Pertimbangan yang diambil yaitu pola fikir siswa sudah masuk pada tahap operasi formal. Pengambilan sampel dilakukan tidak secara acak siswa, tetapi dilakukan secara acak kelompok (kelas) dari kelas 10 yang ada. Dipilih dua kelas yaitu kelas X-RPL 3 sebagai kelas penemuan terbimbing dan kelas X-MM sebagai kelas saintifik. Karakteristik dari kedua kelas ini berdasarkan wawancara dengan guru di sekolah tersebut dikatakan bahwa tingkat keaktifan siswa kedua kelas tersebut tergolong tinggi tetapi di lihat dari hasil belajar siswa untuk kelas X-RPL 3 sedikit lebih unggul dibandingkan dengan kelas X-MM.

Instrumen yang digunakan dalam penelitian ini adalah instrumen tes terdiri dari instrumen tes awal dan tes akhir. Tes kemampuan penalaran matematis ini berbentuk uraian. Tes ini bertujuan untuk mengetahui kemampuan kognitif siswa yang terdiri dari tes awal dan tes akhir. Tes awal digunakan untuk mengetahui kemampuan awal siswa kelompok eksperimen dan kontrol sebelum mendapatkan perlakuan serta untuk mengetahui kesetaraan kedua kelompok tersebut. Sedangkan tes akhir bertujuan untuk mengetahui kemampuan penalaran matematis siswa setelah mendapat perlakuan berupa pembelajaran. Indikator instrumen yang digunakan dalam penelitian ini meliputi: siswa dapat menemukan penyelesaian atau pemecahan masalah dengan mengggunakan fakta yang telah dibuktikan, siswa dapat menarik kesimpulan dan yang berhubungan dengan kemampuan menilai implikasi dari suatu argumentasi, siswa dapat melihat hubungan-hubungan antara ide-ide, dan kemudian mempergunakan hubungan itu untuk memperoleh ide-ide lain, siswa dapat mengikuti argument logis dan siswa dapat menguji konjektur dan memberikan kontra contohkontra contoh. Sebelum instrumen digunakan dalam penelitian, terlebih dahulu dilakukan uji instrumen. Berikut merupakan hasil dari uji coba instrument.

Tabel 1. Data Hasil Uji Validitas Tiap Butir Soal

\begin{tabular}{ccc}
\hline No. Soal & Validitas & Interpretasi \\
\hline 1 & 0,756 & Validitas Tinggi \\
2 & 0,693 & Validitas Tinggi \\
3 & 0,594 & Validitas Sedang \\
4 & 0,635 & Validitas Tinggi \\
5 & 0,569 & Validitas Sedang \\
\hline
\end{tabular}

Data dalam penelitian ini merupakan data berbentuk kuantitatif yaitu tes awal dan tes akhir. Pengolahan data kuantitatif dilakukan dengan menggunakan uji statistik terhadap hasil data pretes dan indeks gain (normalized gain) dari kelas penemuan terbimbing dan kelas saintifik. Indeks gain ini dihitung dengan rumus indeks gain dari Meltzer (Hake, 2007), yaitu:

$$
\text { IndeksGain }=\frac{\text { SkorPosTest }- \text { Skor PreTest }}{\text { SMI }- \text { Skor PreTest }}
$$

Adapun untuk kriteria rendah, sedang dan tinggi mengacu pada kriteria (Hake, 2007) yaitu sebagai berikut: 


$$
\begin{aligned}
& \text { IndeksGain }<0,30 \quad: \text { Rendah } \\
& 0,30 \leq \text { IndeksGain } \leq 0,70: \text { Sedang } \\
& \text { IndeksGain }>0,70 \quad: \text { Tinggi }
\end{aligned}
$$

Pengolahan data kuantitatif dibantu dengan menggunakan program SPSS 17.0 for Windows. Analisis yang dilakukan terhadap data kuantitatif adalah sebagai berikut.

\section{Uji Normalitas}

Uji normalitas diperlukan untuk mengetahui data berdistribusi normal atau tidak. Pengujian dilakukan dengan menggunakan uji Shapiro-Wilk dengan taraf siginfikansi ( $\alpha$ ) 5\%. Jika data yang diperoleh berdistribusi normal, maka selanjutnya dilakukan pengujian homogenitas. Sedangkan jika data yang diperoleh tidak berdistribusi normal, maka tidak dilakukan pengujian homogenitas, tetapi dilakukan pengujian kemampuan dengan menggunakan uji non parametrik.

\section{Uji Homogenitas}

Uji homogenitas dilakukan jika data yang diperoleh berdistribusi normal. Uji ini bertujuan untuk mengetahui apakah kedua kelas memiliki varians yang sama (homogen) atau tidak.

\section{Uji Perbedaan Rerata}

Melakukan uji kesamaan dua rata-rata pada data pretes atau gain kedua kelompok untuk kemampuan penalaran matematis. Hipotesis yang diajukan adalah:

$\mathrm{H}_{0}: \mu_{1}=\mu_{2}$ Tidak terdapat perbedaan rerata kemampuan siswa yang memperoleh pembelajaran penemuan terbimbing dengan siswa yang memperoleh pembelajaran saintifik.

$\mathrm{H}_{1}: \mu_{1} \neq \mu_{2} \quad$ Terdapat perbedaan rerata kemampuan siswa yang memperoleh pembelajaran penemuan dengan siswa yang memperoleh pembelajaran saintifik.

\section{Uji Non Parametrik Mann-Whytney}

Jika data tidak berdistribusi normal selanjutnya melakukan uji kemampuan pada data pretes kedua kelompok untuk kemampuan komunikasi dan penalaran matematis. Hipotesis yang diajukan adalah:

$\mathrm{H}_{0}: X=Y \quad$ Tidak terdapat perbedaan kemampuan siswa yang memperoleh pembelajaran penemuan terbimbing dengan siswa yang memperoleh pembelajaran saintifik.

$\mathrm{H}_{1}: X \neq Y \quad$ Terdapat perbedaan kemampuan siswa yang memperoleh pembelajaran penemuan terbimbing dengan siswa yang memperoleh pembelajaran saintifik.

\section{Hasil Penelitian dan Pembahasan}

Penelitian ini bertujuan untuk menelaah perbedaan peningkatan kemampuan penalaran matematis antara siswa yang memperoleh pembelajaran penemuan terbimbing dengan siswa yang memperoleh pembelajaran saintifik. Pada penelitian ini, tes kemampuan penalaran matematis siswa, baik kelas saintifik maupun kelas penemuan terbimbing dilakukan sebanyak dua kali, yaitu sebelum pembelajaran berlangsung dan setelah pembelajaran selesai dilaksanakan. Data hasil penelitian ini selanjutnya dibandingkan dan dianalisis melalui 
pengujian statistik. Pengolahan data hasil penelitian dilakukan dengan menggunakan software SPSS 19, dan Microsoft Excel 2010. Hasil analisis data penelitian secara kuantitatif diuraikan sebagai berikut.

Nilai rata-rata dan simpangan baku untuk data pre-test, dan $\mathrm{N}$-Gain kemampuan penalaran dapat dilihat pada tabel berikut.

Tabel 2. Statistik Deskriptif Kemampuan Penalaran Matematis Siswa

\begin{tabular}{|c|c|c|c|c|c|c|c|c|}
\hline \multirow{2}{*}{ Kemampuan } & \multicolumn{4}{|c|}{ Kelas Penemuan terbimbing } & \multicolumn{4}{|c|}{ Kelas Saintifik } \\
\hline & $\mathrm{n}$ & & Tes awal & Gain & $\mathrm{n}$ & & Tes awal & Gain \\
\hline \multirow{4}{*}{$\begin{array}{l}\text { Penalaran } \\
\text { Matematis }\end{array}$} & \multirow{4}{*}{31} & $\overline{\bar{x}}$ & 27,74 & 0,50 & \multirow{4}{*}{31} & $\overline{\bar{x}}$ & 10,55 & 0,42 \\
\hline & & S & 15,19 & 0,18 & & S & 6,53 & 0,16 \\
\hline & & Maks & 60,00 & 1,00 & & Maks & 30,00 & 0,63 \\
\hline & & Min & 1,00 & 0,12 & & Min & 0,00 & 0,07 \\
\hline
\end{tabular}

Skor Maksimal Ideal: 100

Berdasarkan tabel 2 diperoleh analisis sebagai berikut.

1. Rata-rata skor tes awal kelas penemuan terbimbing dan kelas saintifik masing-masing sebesar 27,74 dan 10,55. Selisih rata-rata skor tes awal kedua kelas sebesar 17,19, ini berarti diperoleh dugaan bahwa kemampuan awal kedua kelas adalah berbeda karena selisih rata-rata skor kedua kelas tersebut jauh berbeda. Sedangkan rata-rata skor gain kelas penemuan terbimbing dan kelas saintifik masing-masing sebesar 0,50 dan 0,42. Selisih rata-rata skor gain kedua kelas sebesar 0,08, ini berarti diperoleh dugaan bahwa peningkatan kemampuan kedua kelas dalam penalaran matematis adalah tidak jauh berbeda. Jika melihat kepada rata-rata skor gain, maka diperoleh dugaan bahwa tidak terdapat perbedaan yang signifikan peningkatan kemampuan penalaran matematis kelas penemuan terbimbing dengan kemampuan penalaran matematis kelas saintifik. Namun, untuk memastikan dugaan tersebut, dilakukan pengujian statistik pada bagian selanjutnya.

2. Simpangan baku untuk tes awal kelas penemuan terbimbing sebesar 15,19 sehingga ratarata penyebaran data tes awal kelas penemuan terbimbing di sekitar nilai rataratanya sebesar 13,54. Sedangkan simpangan baku tes awal kelas saintifik sebesar 6,53 sehingga rata-rata penyebaran data tes awal di sekitar nilai rata-ratanya sebesar 6,53. Ini berarti penyebaran data tes awal kelas penemuan terbimbing lebih rapat dibandingkan penyebaran data kelas saintifik. Simpangan baku skor gain kelas penemuan terbimbing dan kelas saintifik masing-masing sebesar 0,18 dan 0,16 sehingga diperoleh bahwa penyebaran skor gain kelas penemuan terbimbing lebih rapat dari pada penyebaran data kelas saintifik.

Berdasarkan analisis deskriptif, terlihat bahwa rata-rata peningkatan ( $N$-gain) kemampuan penalaran siswa yang memperoleh pembelajaran dengan penemuan terbimbing tidak jauh berbeda dari siswa yang memperoleh pembelajaran dengan saintifik, jika ditinjau secara keseluruhan siswa. Untuk lebih menguatkan hasil dari analisis statistik deskriptif, berikut merupakan hasil dari analisis statistik inferensial data kuantitatif 
Tabel 3. Data Uji Normalitas Data $\mathrm{N}$-gain Kemampuan Penalaran Berdasarkan Model Pembelajaran

\begin{tabular}{|ll|c|c|c|}
\hline \multirow{2}{*}{} & \multicolumn{3}{|c|}{ Shapiro-Wilk } \\
\cline { 3 - 4 } & Model pembelajaran & Statistic & $\mathrm{df}$ & Sig. \\
\hline Gain Penalaran & penemuan terbimbing & .967 & 31 & .438 \\
& Saintifik & .903 & 31 & .008 \\
\hline
\end{tabular}

Berdasarkan tabel tersebut, nilai signifikansi uji Shapiro-Wilk kelas saintifik adalah $0.008<0.05$, sehingga $\mathrm{H}_{0}$ ditolak. Dengan demikian data $N$-gain di kelas saintifik tidak berdistribusi normal. Namun, nilai signifikansi uji di kelas penemuan terbimbing adalah 0.438 $>0.05$, sehingga $\mathrm{H}_{0}$ diterima. Artinya data $N$-gain di kelas penemuan terbimbing berdistribusi normal. Berdasarkan uji normalitas data, data di kelas saintifik tidak berdistribusi normal, sehingga pengujian hipotesis dilakukan dengan uji non-parametrik Mann-Whitney $U$ pada taraf $\alpha=0.05$. Adapun hasil pengujian ini dapat dilihat pada tabel berikut.

Tabel 4. Data Uji Mann-Whitney $U$ Data $N$-gain Kemampuan Penalaran

\begin{tabular}{|l|c|}
\hline & Gain Penalaran \\
\hline Mann-Whitney $U$ & 353.500 \\
Sig. (2-tailed) & .074 \\
\hline
\end{tabular}

Berdasarkan Tabel 4 dan kriteria pengujian di atas, terlihat bahwa nilai signifikansi (2tailed) adalah sebesar 0,074. Karena 0,074 lebih dari 0,05, ini berarti tidak terdapat perbedaan yang signifikan peningkatan kemampuan penalaran matematis siswa pada kelas saintifik dengan kelas penemuan terbimbing.

Berdasarkan hasil pengolahan data yang dihasilkan, bahwa Peningkatan kemampuan penalaran kelas penemuan terbimbing secara keseluruhan tergolong pada kategori sedang. Peningkatan kemampuan di kelas ini cukup signifikan, hal ini sejalan dengan pendapat dari Marzano (Markaban, 2006) bahwa dengan menerapkan pembelajaran penemuan terbimbing, materi yang dipelajari dapat mencapai tingkat kemampuan yang tinggi dan lebih lama membekas pada diri siswa. Disamping itu, peningkatan kemampuan penalaran kelas saintifik secara keseluruhan tergolong pada kategori sedang. Peningkatan kemampuan di kelas ini juga cukup signifikan, hal ini sejalan dengan prinsip dari pembelajaran saintifik yang mengedepankan penalaran (Kemendikbud, 2014). Selain itu, proses pembelajaran dikembangkan atas prinsip pembelajaran siswa aktif melalui kegiatan mengamati, menanya, menganalisis (menghubungkan, menentukan keterkaitan, membangun konsep), dan mengomunikasikan (lisan, tulis, gambar, grafik, tabel, chart, dan lain-lain) (Kemendikbud, 2014). Tetapi jika dikaitkan dengan pecapaian siswa dalam artian melihat hasil tes akhir siswa, dari hasil akhir untuk kelas penemuan terbimbing dan saintifik diperoleh rata-rata pencapaian kemampuan penalaran adalah 63.39 dan 48.19.

Berdasarkan hasil rata-rata tersebut bisa disimpulkan bahwa pencapaian siswa masih rendah karena masih jauh dari KKM yang ditetapkan oleh sekolah. Sehingga diperoleh 
temuan bahwa penerapan pembelajaran penemuan terbimbing tidak bisa sembarangan digunakan dalam kata lain harus memperhatikan kemampuan awal siswa pada suatu kelas. Jika dibandingkan antara hasil tes akhir kemampuan penalaran kelas penemuan terbimbing dengan kelas saintifik secara statistik diperoleh bahwa pencapaian kemampuan penalaran matematis kelas penemuan terbimbing lebih baik dibandingkan kelas saintifik. Hal ini dikarenakan kemampuan awal penalaran matematis kedua kelas itu berbeda secara signifikan.

\section{Kesimpulan}

Berdasarkan hasil penelitian dan pembahasan, dapat disimpulkan bahwa tidak terdapat perbedaan yang signifikan dari peningkatan kemampuan penalaran matematis siswa pada kelas saintifik dengan kelas penemuan terbimbing. Hal ini ditunjukkan dengan nilai signifikansi (2-tailed) hasil uji Mann-Whitney $U$ pada data $\mathrm{N}$-gain yaitu sebesar 0,074 di mana nilai ini lebih besar dari alpha 0,05 .

\section{Daftar Pustaka}

BSNP.(2006). Standar Isi Untuk Satuan Pendidikan Dasar dan Menengah. Jakarta

Hake, R. R. (2007). Design-Based Research in Physics Education Research: A Review.[Online].Tersedia:http://www.physics.indiana.edu/ hake/DBRPhysics3.pdf [20 September 2012]

Markaban. (2006). Model pembelajaran matematika dengan penemuan terbimbing. Jogjakarta : Depertemen Pendidikan Nasional

Nasution. (2009). Berbagai Pendekatan dalam Proeses Belajar dan Mengajar. Jakarta: PT Bumi Aksara

Ruseffendi, E.T. (2010). Dasar-dasar Penelitian Pendidikan \& Bidang Non-Eksakta Lainnya. Bandung: Tarsito.

Shadiq, F. (2009). Kemahiran Matematika. Jogjakarta :Depertemen Pendidikan Nasional.

Sumarmo, Utari. (2013). Berfikir dan Disposisi Matematik Serta Pembelajaranya. UPI Bandung : FPMIPA-UPI

Wahyudin.(2007). Strategi Belajar Mengajar Matematika. UPI Bandung : FPMIPA-UPI

Wahyudin.(2014). Beberapa Konsep Esensial dalam Penelitian. UPI Bandung : FPMIPA-UPI 